\title{
REBUILDING TERTIARY EDUCATION IN GUINEA-BISSAU: CAN IT BE DONE? ${ }^{1}$
}

\author{
Brandon D. Lundy ${ }^{2}$ \\ Kennesaw State University, USA
}

\begin{abstract}
This article evaluates the potential for rebuilding tertiary education in GuineaBissau focusing on the reconstitution of the Universidade Amílcar Cabral, the operations of Universidade Lusófona da Guiné, and the development of the Bissau Campus Project through the West African Vocational Schools (WAVS) project. The article considers available resources and contextual constraints in the face of underdevelopment, structural violence, neo-colonialism, and a context-specific educational legacy. In the face of considerable barriers to rebuilding tertiary education in Guinea-Bissau, how can it be done? Achievements in other contexts, and specific recommendations for Guinea-Bissau, are aggregated to demonstrate how collaborating stakeholders can amalgamate knowledge and develop viable educational programs that are contextually sensitive, appropriate, and sustainable.
\end{abstract}

Keywords: Guinea-Bissau; Tertiary Education; Program Development; Partnerships; CoCreation of Knowledge; Program Assessment; Amilcar Cabral; Paulo Freire

\section{Introduction}

Education in general and tertiary education in particular are both social and political constructions (Langa 2014). Because of protracted political instability since independence in which no elected president has served-out his full term in office (Kohl 2016) and the accompanying securitization failures in the West African country of Guinea-Bissau (Massey 2016), a stable tertiary education sector does not seem likely. Yet, with the successful elections of 2014, "The new government enjoyed much popular support, and Bissau-Guineans were in an optimistic mood, evoked by many

\footnotetext{
${ }^{1}$ This article helps lay the foundation for a Fulbright Specialist Program Host Institution Project Proposal titled "Understanding Human Ecology in Guinea-Bissau" submitted through the U.S. Embassy, Dakar's Exchange Program Specialist, Public Affairs Section. The project is a collaborative effort at building viable educational opportunities for students, faculty, and administrators across institutions of Higher Education. I would like to thank my host country counterparts at Universidade Amílcar Cabral and Universidade Lusófona da Guiné, for their valuable insights on the current state of affairs of Higher Education in GuineaBissau. I would also like to acknowledge the leadership of the West Africa Vocational Schools (WAVS) program, from which I have also learned a great deal about alternative possibilities for tertiary education in the country.

2 Correspondence: School of Conflict Management, Peacebuilding and Development at Kennesaw State University, 365 Cobb Avenue NW, Kennesaw, GA 30144, USA; E-mail: blundy@kennesaw.edu.
} 
improvements that the new government managed to achieve with strong international financial support" (Kohl 2016, 163). Security sector reforms were restarted, state employees began to receive their overdue salaries, corruption was in decline, and public infrastructural improvements were seen throughout the capital city of Bissau, until President Vaz provoked a constitutional crisis by dismissing Prime Minister Pereira and his popularly supported government (Kohl 2016). This article embraces this contextual dilemma by exploring the rebuilding of tertiary education in Guinea-Bissau within this unstable political terrain. Lessons learned from other educational projects enacted throughout Africa are presented, ongoing higher educational initiatives in Guinea-Bissau are explored, and a proposal for successfully advancing these education necessities is provided at the end. As will be shown, rebuilding tertiary education in Guinea-Bissau is underway, but finding effective interventions that can ensure its sustainability and effectiveness within this unstable climate remain elusive.

\section{Setting the Stage}

Global structural inequality (for example, see Boehler and Ceesay 2013; Yaoti 2016) has disadvantaged the West African nation-state of Guinea-Bissau since before its recognition on the world stage as a sovereign nation in 1974. The tri-fold problems of underdeveloped institutional capacity, neocolonialism, and structural violence infect its politics and destabilize its social institutions including education (Boone et al. 2013; Silva and Oliveira 2017; UNICEF 2016). According to the Agence France-Presse (AFP), "Long-running pay disputes have kept teachers out of the classrooms for long stretches of the last four decades in this former Portuguese colony, where a dysfunctional government struggles to provide basic services to its citizens" (2017). The report goes on to cite UNESCO's decree of " 40 years of institutional instability" in Guinea-Bissau and The National Institute for the Development of Education's (Portuguese: INDE) stats that show, "just 30 percent of the curriculum on average was completed in primary and secondary schools in the last 20 years" (AFP 2017). Again citing UNESCO and World Bank figures, the report concludes that even though households contributed "63 percent of the country's total educational expenditure" out of their meagre per capita income of around $\$ 620$ per year, this was still “one of the lowest" proportions of any national budget on the continent earmarked for education (AFP 2017).

Guinea-Bissau is a country built out of geographic and historical necessity and happenstance as a refuge of coastal and inland groups fleeing the rise and fall of West African empires and their inevitable suppression of surrounding groups (Rodney 1970). Subjected to the indigenous hegemonies of the Mandinka, Susu, and Fula and external hegemonies of the Portuguese, French, and Cabo Verdean Creoles, the entrenched populations endured, transforming the landscape into a patchwork of ethnic enclaves, power associations, and variously aligned patrimonial networks.

Out of this bricolage, agronomist-leader and culture hero Amílcar Cabral through the African Party for the Independence of Guinea and Cape Verde (Portuguese: Partido Africano da Independência da Guiné e Cabo Verde, PAIGC) mobilized this disparate agrarian population into an unaligned, world-class military force and political movement that overthrew the colonial regime while simultaneously enacting nation-building. A significant part of Cabral's vision of unity and struggle revolved around developing education, both for youth and adults (Freire 1978; Lundy 2013). According to Cabral,

The difficulties of our struggle were mainly those inherent in our situation as an underdeveloped ... people ... A people that started with nothing, a people with 99 percent illiteracy rate-you have already seen the effort that we have to make now to teach our people to read and write, to create schools - a people that had only 14 university-trained men ... It is a 
struggle for schools, for hospitals, so that children won't suffer. That is our struggle. (1969, 143, 145-146)

Cabral's vision for Guinea-Bissau faltered, however, with his assassination and subsequent post-independence moves to secure power by various factions operating within and beyond the state (Green 2016; Vigh 2012). Since independence, the country has witnessed the ouster of Luís Cabral in 1980, a violent conflict that removed João Bernardo "Nino" Vieira from office in 1999, a military coup against Kumba Ialá in 2003, the return to power of Nino Vieira in an electoral surprise in 2005, his violent assassination in 2009, and the election of Malam Bacai Sanhá in 2009, where he died in office in 2012 plunging the country yet again into political turmoil. More detailed periodization of Guinea-Bissau's political instability can be found elsewhere (for example, see Chabal and Green 2016). Acknowledging this protracted political turmoil, Langa (2014, 46) concluded, "The coup d'état of 12 April 2012, which took place between the two rounds of the presidential election, plunged the country into serious mayhem."

Galtung's (1969) concept of "structural violence" seems apropos here as barriers to quality education deepen in Guinea-Bissau through the "factionalization" of the political and social institutions (Vigh 2012) alongside a neocolonial legacy of underdevelopment (Rodney 1982; Vigh 2006) that is preventing people from meeting their basic needs. Cognitively reframing this fatalistic view of young people hopelessly struggling "to expand their horizons of possibility in a world of conflict, turmoil and diminishing resources" (Vigh 2006) is an essential aspect of rebuilding hope and opportunity in Guinea-Bissau (for example, see Temudo and Abrantes 2015). Recognizing this relationship between poverty and education, "Guinea-Bissau's education sector plan is in line with the poverty reduction strategy, which recognizes that the education sector has been negatively affected by the country's state of crisis" (Global Partnership for Education 2017; see also Silva and Oliveira 2017). By 2015, Guinea-Bissau had 9.2 "expected years of schooling" with an actual "mean years of schooling" of only 2.9 years. While these are up from previous years, it still ranks Guinea Bissau in the "low human development" category, at $178^{\text {th }}$ out of 188 countries (HDI: 0.424) (UNDP 2016). With such intense long-term political disruption, inequality, and poverty in Guinea-Bissau, how can tertiary education be injected with new-life that overcomes this cycle of structural violence?

Finding ways to rebuild tertiary education in Guinea-Bissau must be multifocal (Silva and Oliveira 2017). Therefore, we must be willing to accept lessons learned from various regions and multiple perspectives, only some of which can be advanced here, because, according to Silva and Oliveira (2017), "Guinea-Bissau is also under represented in comparative and international education journals and also it is under-researched" (21).

The most recent figures (2013) on Guinea-Bissau's expenditures on education as a percentage of GDP show only $2.173 \%$ earmarked for education, making it the $170^{\text {th }}$ lowest of 195 countries worldwide (The World Bank Group 2017). Rui da Silva and Joana Oliveira (2017) put it thusly, "The education system also seems to be shaped by political indecision, discontinuities, contradictions, unfinished reforms, inefficiency, instability, great differences between urban and rural areas and it is not appropriate for the reality of the country" (22). These persistent trends hinder the development of tertiary education in Guinea-Bissau. This article considers how educational capacities within the country can be encouraged and expanded. What can best practices from locations sharing similar challenges to growing tertiary education teach us?

\section{Expanding Tertiary Education in Other African Contexts: Lessons Learned}

Successful capacity-building efforts in tertiary education found elsewhere on the African continent should be applicable to the Bissau Guinean context to various degrees. 
Therefore, this section considers a few select "lessons learned" from throughout the continent to glean relevant potential options and areas of further consideration when proposing to rebuild tertiary education in Guinea-Bissau. These lessons helped to frame the questions that were asked to experts within Guinea-Bissau's tertiary education system, the thematic analysis of their responses, and the subsequent structure of the final proposal. This section considers how tertiary education was successfully developed in other African contexts.

To begin, Paracka (2013) studied a long-term partnership between Kalamazoo College in Michigan and Fourah Bay College in Freetown, Sierra Leone. Based on his analysis of this international study abroad partnership, he found that reciprocity and bidirectional benefits were key factors in successful and fair-minded capacity building efforts.

Reciprocity is a broad construct that not only includes financial considerations but also focuses on the educational goal of obtaining a true exchange of ideas and values, including those that may be in conflict. The greatest value of study abroad with African partners is the potential to develop mutual understanding around common interests and problems in order to foster greater collaboration. (Paracka2013, 207-208)

Paracka found that for effective communication, interaction, and learning to emerge, defining explicit and transparent common interests was essential. He concludes,

Study abroad programs with African partners should be conceived as part of a larger effort by U.S. colleges and universities to effectively build relationships, conduct joint research, deliver classroom instruction, and collaborate on joint projects. ... Such programs need to be strategically integrated within degree programs and across disciplines. (Paracka 2013, 209)

Undeniably, tertiary educational initiatives in Guinea-Bissau must be transparent, reciprocal, and strategically integrated whether originating from a local initiative or international partnership.

Drawing on many years of knowledge and research experiences in Tanzania, Ellison (2013) shows us another interdisciplinary approach supporting tertiary development. An ethnographic field school offers an unparalleled opportunity for experiential learning that transforms the lives and careers of not only the host but also the guest participants. The collaborative program takes the learning environment outside of the classroom where the students (both foreign and domestic) spend "time with Tanzanians in their communities to understand their everyday social and cultural lives and their articulations with national and transnational forces" (Ellison 2013, 216). These educational encounters encourage collaborative peer-to-peer learning, connecting student experiences with ground level realities. In resource poor environments, an "all hands on deck" approach should be the norm in which efforts draw on the strengths of the whole (Freire 1996).

Similarly, Finnegan, Atim, and Westerhaus (2013) taught global health in northern Uganda through "problem-based initiatives combining reflection and action (praxis)" that offered "empowerment in the learning process and partnership between teachers and students" (227). They argue that in any collaborative enterprise, power and privilege differentials must be acknowledged, engaged, and worked through to achieve successful joint programming. A collaborative course on public health was offered to both Ugandan and U.S. physicians and social scientists, rotating between the classroom and 
health clinics throughout the countryside. They opine, "Exploring the linkages between power on a personal level and the global systems of structural violence and hierarchy requires the creation of an equitable classroom conducive to collaboration" (Finnegan, Atim, and Westerhaus 2013, 230). The multidisciplinary students in the program enhanced "learning by bringing in a plurality of perspectives to the subjects tackled. It promoted respect and sensitivity" (Finnegan, Atim, and Westerhaus 2013, 231). Recognizing inequalities within the classroom forced the instructors to "proactively work to build equity in the classroom" (Finnegan, Atim, and Westerhaus 2013, 232). Equity, trust, and collaboration were accomplished through dialogue and openness, creating more "humanizing understandings of one another" (Finnegan, Atim, and Westerhaus 2013, 234, see also Farmer 2005).

According to Negash and Bass (2013) working in Ethiopia, "Higher Education was willfully neglected in Africa during the late $20^{\text {th }}$ century" (240; see also Bloom et al. 2006) with African government officials working with limited resources targeting primary and secondary education to the detriment of tertiary education spending. Structural adjustment programs also "actively discouraged higher education investment in low-income countries. University funding was reduced, causing deterioration in staff working conditions, the built environment, and research capacity" (Negash and Bass 2013, 240). The authors of this study show how they were able to successfully help build an IT Ph.D. program in Ethiopia through limited resources by engaging with and developing transnational intellectual communities. Negash and Bass explained that when Ph.D. candidates were sent abroad to study, most did not return. However, utilizing similar faculty resources by bringing them to Ethiopia for short stays or working remotely with Ph.D. candidates at local universities was helping to increase the indigenous research-active faculty in the country. This model can be replicated elsewhere to help combat the significant problems of brain drain experienced in underdeveloped countries. By relying on transnational collaboratively staffed programs developed locally, a critical mass of indigenous talent able to take over educating the population is possible. This approach was referred to by Negash and Bass as the "educating-the-educators" model, which they show can be highly effective in rebuilding African higher education.

Lastly, taking into account the local context is crucial to successfully rebooting tertiary education in Guinea-Bissau. Using "cultural capital” (Lundy 2013), it is possible to establish an essential approach to education in Guinea-Bissau by ensuring that educational initiatives and projects seriously consider local contexts and realities. If this is not heeded, the likely result is an ineffective "Europeanisation in education" in which the organization, duration, and degrees reflect standards and options unsuitable for the Bissau-Guinean context (Silva, Santos, and Pacheco 2015, 993-4).

Throughout the independence movement, PAIGC worked to promote educational reforms in the country by increasing scientific and technical capacity, by offering free universal education aimed at eliminating illiteracy, by dismantling the colonial educational system, and by "striking a balance between preserving tradition and modernizing ... to achieve mass acceptance ... through culturally accepted mechanisms" (Lundy 2013, 368; see also Harasim 1983, 111). It was the PAIGC boarding schools, however, that helped create the petit bourgeois or "new proto-military class - a class that subsequently came to dominate postcolonial independence politics" (Dhada 1993, 112). By 1975, PAIGC enlisted Paulo Freire to assist in building their national adult literacy program based "on the people's reality" (Lundy 2013, 365). "Despite Freire's emphasis on culture as a foundation for education, he was only able to partially grasp the cultural [political, and economic] realities affecting Guinea-Bissau during his brief encounter" (Lundy 2013, 371), something he candidly acknowledged in his own writings (Freire and Macedo 1995). While Freire's efforts were largely unsuccessful, this approach still has potential. "Education starts with a shared understanding and empathy between 
administration, teachers, parents, and pupils. By knowing and understanding their students, they can help position them to succeed in the Bissau-Guinean context and challenge the unequal global system" (Lundy 2013, 373).

What can be learned from these empirical studies on the building of tertiary education in Africa is that "Education ... must be exploited, nurtured, valued, advanced, developed, shared, and disseminated freely as a common good" (Pityana 2013, 383). More specifically, educational capacity building must be transparent, reciprocal, and strategically integrated. Successful initiatives must be internationally collaborative enterprises (e.g., peer-to-peer) where power and privilege differentials are acknowledged, engaged with, and worked through at all levels. Furthermore, a localized educating-theeducators model can build capacity while avoiding pitfalls such as the previously experienced brain drain throughout the African continent. Finally, any educational initiatives must work within localized historical and cultural realities, economic constraints, and shifting political will. Next, I briefly provide a description of these tertiary and higher education realities in Guinea-Bissau.

\section{Tertiary/Higher Education in Guinea-Bissau}

The endeavor of rebuilding tertiary and higher education in Guinea-Bissau has a history (Silva and Oliveira 2017). For example, in 1979, Urdang wrote,

The very process of education was itself helping to develop a new society. The students were being prepared for a future that did not yet exist, and in this way were themselves molding the future. Their education was insurance that the revolutionary direction of the society into which they would pass would be carried forward. "Our type of education," said Cabral, "has to be conditioned in each phase of the struggle by the life and history we experience at a given moment." (171)

These struggles toward "a future that did not yet exist" continue, however, with GuineaBissau's contemporary educational objectives remaining largely unrealized. Headlines continue to read "Guinea-Bissau still way behind on education" (IRIN 2013) and "GuineaBissau Struggles to Provide Education" (Shipman 2015). These problems of inadequate educational capacity and provisioning are protracted. One of the few publications on higher education in Guinea-Bissau acknowledged that at the time of publication, there were no public universities in the country (Langa 2013, 47). Indeed, few positive educational developments were discernable for Guinea-Bissau in Langa's book, Higher Education in Portuguese Speaking African Countries: A Five Country Baseline Study (2013). Langa (2013) concludes, "While it can be argued that Guinea-Bissau's higher education has evolved and transformed significantly since its inception in the 1970s, the ultimate effects of these changes on the underlying character of the of the country's higher education have not led to the constitution of an integrated higher education system" (46$47)$.

The Instituto National de Estudos e Pesquisa (INEP), a national research institute founded in 1984, remains the only such institution operating in the country. INEP has five major research centers (Historical and Anthropological Studies, Environmental Studies, Socio-Economic Studies, Strategic and International Studies, and the Project Management Office) and multiple other research units and houses the National Library with over 70 thousand reference materials and the National Historical Archives (AHN), which contain more than 16,000 historical documents. The institution's mission is to promote the investigation of the social and natural sciences related to issues of 
development in Guinea-Bissau and to mobilize local talent to carry out this fundamental work through the building and maintenance of a network of national foreign researchers. ${ }^{3}$ Other attempts at developing similar institutions were ineffective. In 1999, the Government of National Unity under Prime Minister Francisco José Fadul and Minister of Education Galdé Baldé created a short-lived public-private partnership known as the Lusophone University of Amílcar Cabral. While this initiative itself was unsuccessful, I revisit this partnership as a potential framework for rebuilding higher education.

According to Langa (2013),

The Council of Ministers created the Lusophone University Amílcar Cabral (ULAC) by Decree Law 6/99 of 6 December, published in Official Gazette No. 49. The ULAC was managed by a private foundation (PUNPEC - Foundation for Promotion of Education and Culture) made up of the Government of Guinea-Bissau and a private Portuguese university (Lusophone University). For technical reasons ULC began to operate fully at the end of the academic year 2003/2004 [November 13, 2003]. Currently [2013], the ULAC does not operate due to a disagreement between the government and the institution representing Lusophone University. The government removed itself from the joint venture, but Lusophone University continued to offer programmes using Government facilities and premises (Landin 2012, interview). The set of colleges and faculties that were supposed to integrate a comprehensive institution were split up to operate in a school system of non-integrated university. The month of November [3] 2008 marked the end of the joint administration, and the Government of Guinea-Bissau declared the transfer of the administration to its total bilateral partner, Lusophone University of Portugal, thus giving rise to the Lusophone University of Guinea (ULG). (53-4)

The rationale for this public-private partnership was to stop the brain drain of the country's best, brightest, and most educated. According to an IRIN article announcing the opening of ULAC in 2003, "Until now, Guinea-Bissau relied on bursaries to send its students to foreign universities, especially to Portugal, Cuba, and Eastern Europe." The report continued, "about $80 \%$ of all Guineans educated abroad had decided to remain there to work afterwards. They therefore failed to contribute to building this desperately poor nation of 1.3 million people" (IRIN 2003).

By 2011, Mr Rui Landim was spearheading the committee set up by the Ministry of Education to reopen Amílcar Cabral University, which was successfully reconstituted in 2013. Under its newest Rector, Dr. Zaida Maria Lopes Pereira Correia (as of September 20, 2014), and Vice-Rector, Dr. Raul Mendes Fernandes, the public university reopened its activities in 2016, including the establishment of the first university library on June 23, 2016. Furthermore, as of 2016, Amílcar Cabral University is offering courses in law, information technologies, earth sciences and environment, and languages, literature, and culture. It is also offering Masters Degrees in Energy and Natural Resource Law and Telecommunications Law.

"In Guinea-Bissau the body that coordinates and supervises the activities and quality of higher education is the directorate general of higher education, which is part of the organisational structures of the ministry of education" (Langa 2013, 55). Unfortunately, in the last 25 years, Guinea-Bissau has had more than 33 ministers of education, which directly affects any long-term stability, planning, and development

${ }^{3}$ INEP's website is accessible at http://inep.gw/apresentacao.php. 
(Santos and Silva 2017, 206). Compounding the county's educational challenges is the fact that the ICT infrastructure is inadequate and poor. The good news is that Guinea-Bissau will be the last coastal country in West Africa to link to the Africa Coast Europe (ACE) cable in approximately 18 months at a cost of $\$ 47$ million (Rueters 2017). Furthermore, although in 2013 Langa lamented about Guinea-Bissau being an agricultural country with no tertiary agricultural sciences $(2013,56)$, today both Universidade Amílcar Cabral and Universidade Lusófona are developing these very initiatives.

According to the Republic of Guinea-Bissau's "Three-year Plan for the Development of Education: 2011-2013" released in March 2010 and reported by the Ministry of National Education, Culture, Science, Youth and Sports, their plan for technical/vocational (TEVT) and higher education involves the following: For TEVT, develop the overall teaching structure and increase TEVT throughout the country. One important aspect of this will be to "define the nature of public-private partnerships ... [and] to identify which subjects should be prioritized" (Republic of Guinea-Bissau 2010, 29). Oversight will be provided by the Institute for Technical Education and Vocational Training (IFTP). What remains critical to TEVT in Guinea-Bissau is to determine important areas of training emphasis, "to promote public-private partnerships, to set up of a national framework for qualifications and certificates, and to create a reference manual for all training operators and for the national labor market" (Republic of Guinea-Bissau 2010, 29).

For Higher Education and Scientific Research, the "Three-year Plan for the Development of Education" highlighted the fact that were only 3,700 active students, which was 217 per 100,000, compared to "336 on average in francophone and 514 in anglophone Africa” (Republic of Guinea-Bissau 2010, 30). The report also noted the significant amount of underfunding in higher education. The national aims include increasing efficiencies toward accreditation, programming, and titles and diplomas, and promoting scientific research in partnership with centers abroad. Specifically, the report highlights six roles for the state and three for private initiatives.

The role of the state will include:

The creation of a framework for scientific development: endorsement of training models, issue of titles and diplomas; The management of higher education: decisions relating to the opening of institutions, authorizations, management of influx;

Social policy: grants (scholarships) and partial funding of students' work;

Public investment: a university library and laboratories, for which private users will be required to pay a subscription;

Direct creation of some departments/subjects;

The organization of teachers' ongoing training (including research, in partnership with centers abroad).

The role of private initiatives will be oriented towards:

Enabling students to complete their studies;

The management of infrastructures that require ongoing expenditure (laboratories);

The creation of new subject departments, for which they will have to submit tenders. Tenders will be offered in lots, each one consisting of at least one complete department requiring technical investment. (Republic of Guinea-Bissau 2010, 30-31)

Are these initiatives in tertiary education being realized? Before attempting to answer this question, at least preliminarily, first a note on methodology. 


\section{Note on Methodology}

According to Santos and Silva (2017), "Guinea-Bissau constitutes an important case study - an 'observatory' - for the debates on education and fragility that need to be deepened and further researched within Lusophone contexts" (213). My initial thinking about this important case began when I was first invited to serve as an advisor to the West African Vocational Schools' (WAVS, www.WAVSchools.org) Bissau Campus Project. Then, in 2014, I was asked to help write a proposal for a Fulbright Scholar-inResidence through the Council for International Exchange of Scholars to bring Dr. Raul Mendes Fernandes from Guinea-Bissau to Kennesaw State University for the Year of the Portuguese-speaking World program. As part of this exchange program that ran from 2015 to 2016, we had opportunities to collaboratively teach, present, and publish together. It was through this initiative that I learned about his role as Vice-Rector at Amílcar Cabral University and their attempt to rebuild this public institution of higher education in Guinea-Bissau.

Upon his return to Guinea-Bissau, I was added to the Fulbright Specialist Roster through the U.S. Department of State's Bureau of Educational and Cultural Affairs (ECA) and World Learning. It was at that time that we began collaborating on the development of a Fulbright proposal on "Understanding Human Ecology in Guinea-Bissau", which is intended to be a workshop and program development between the Universidade Amilcar Cabral and Universidade Lusófona da Guiné. In order to lay the foundation for this project proposal, I sent a survey by email to institutional contacts at WAVS, Universidade Amilcar Cabral, and Universidade Lusófona da Guiné.

Questions included: Based on your experiences, what are the most important resources available to students studying at your institution? Based on your experiences, what are your institutions major constraints toward providing quality higher education? Do you personally collaborate with other faculty, students, or institutions of higher education besides the one you work for? Based on your experiences, what is the future of higher education in Guinea-Bissau? Do these align with the mission of your institution? Responses were then thematically analyzed based on the categories identified in the literature related to other African-specific tertiary educational initiatives including identified barriers and lessons learned. The preliminary findings are based on responses to these questions from respondents from each of the three institutions.

\section{Preliminary Findings}

To maintain confidentiality, based on the low number of respondents $(<5)$ and due to the sensitive nature of some of these responses, I do not attribute any of the direct quotes being used in the preliminary findings that are used to illustrate major themes in the data. The thematic categories were deductively anticipated based on the review of the relevant literature. Thematic analysis was performed based on a coding structure tied to the nine identified thematic categories, which are: Underdevelopment, Neocolonialism, Structural Violence, Brain Drain, Strategic Integration, Collaboration, Building Capacity, Localized Realities, and Future Potential.

\section{Underdevelopment}

Rodney (1982, 13-29) defines underdevelopment as (1) social and economic unevenness; (2) exploitative relationships; (3) weak industry and social services; (4) lopsided foreign trade, investment, and privatization; (5) structural dependence; and (6) political subordination and instability. As Amílcar Cabral (1969) acknowledged, GuineaBissau's educational system was woefully underdeveloped at the time of independence, and while tertiary education has improved slightly overall (Republic of Guinea-Bissau 2010; UNICEF 2016), indices such as the UNDP's Human Develop Index (2016) 
continue to show that Guinea-Bissau's educational situation remains tenuous. Similarly, study respondents expressed comparable sentiments related to tertiary education's underdevelopment in Guinea-Bissau:

On a global level, the school is operating at the most basic level. We have only the most basic technology in use and even in that we are not using them to their full capabilities. Because of the harsh conditions of GuineaBissau (dust, humidity, heat), many of the tech items don't last their full lifetime. Technology is expensive to purchase (especially good quality technology) in Guinea-Bissau, so we bring over a lot of our technology in use from the US, but that makes getting replacement parts difficult.

Another described a disruption in services due to underfunding and the inability of the government to support public education: "With the end of this agreement, the university couldn't continue without effective support from the government." A third respondent reframed these concerns are reflective of the populations resilience: "The resilience or the capacity to resist pressures from the lack of financial and material means, the lack of institutional support, and political instability [is essential for knowledge creation], and to be strong to continue through adversities."

Other issues related to underdevelopment concerned the direct lack of necessary resources to operate adequately. For example, "Information and communication technology is extremely deficient. Students have trouble accessing information, online literature, and email. Also, many students do not have a computer and lack the means to purchase one. Accessible computers with and/or without internet are lacking." Another said, "Also, libraries, internet and an open space for students to work during the day and evening would also be important since many do not have electricity at home. Courses for professors to improve their teaching methods and reflect on the needs of students are also very much needed."

Many of these concerns about the underdevelopment of both Guinea-Bissau generally and tertiary education specifically have neocolonial roots. Therefore, expressions related to neocolonialism was the second area examined.

\section{Neocolonialism}

Kwame Nkrumah (1965) saw neocolonialism as "the economic, political, and social influences that Western countries use to control Africa and other formerly colonized continents" (Marquardt 2013, 57). While direct and explicit references from respondents to former colonial powers meddling in higher education was not observed in the data, it is important to note that Guinea-Bissau has only one public university. Private tertiary education options are funded through bilateral and multilateral agreements with nonprofit institutions in Europe and the United States. Furthermore, the government and Ministry of Education receive direct funding and loans from the United Nations, World Bank, The Organisation for Economic Co-operation and Development's (OECD) Development Assistance Committee (DAC), and many others, which suggests a tremendous amount of direct influence in higher education (Silva, Santos, and Pacheco 2015).

Universidade Amílcar Cabral (UAC) was first established in 1999 under the management of the private Foundation for the Promotion of Education and Culture (FUNPEC) between the Government of Guinea-Bissau and the Portuguese private university, Universidade Lusófona. By November 3, 2008, the government claimed that it could no longer financially support the institution, giving full control over to its partner, Universidade Lusófona. The rector at the time, Alberto Sanhá, stated on the record that this was "dirty business" (read: corrupt) (Sami 2008). Furthermore, the 
Association of Teachers of UAC also questioned the legitimacy of the change, calling for the intervention of the Public Prosecutor's Office to carry out an audit over financial management of the university (Sami 2008).

Another example of neocolonial practices potentially jeopardizing tertiary education opportunities in the country relates to the transference of land from a private university to the West African Vocational Schools (WAVS) Bissau Campus Project. According to a knowledgeable WAVS administrator, "Currently, acquiring land to build a second campus in the capital has been a major constraint to the growth of our organization. This constraint has mainly been caused by constantly changing people in power at the government level. ... We are still in collaboration with the university on acquiring the land due to government delays in legalization of the land transfer." He continued,

We arrived in Bissau unsure about how we should re-start the process of securing the land in Antula after the government collapsed during our previous attempt earlier in the year. We began by meeting with ... [representatives from the university, Ministry of Territory, and Camara Municipal (local government office)] to work out a deal that will resolve the years-long dispute ... Of that remaining land, Camara is willing to donate "four or five hectares" to WAVS. This means the agreement would be just between WAVS and Camara.... [The local government official] also said that we will have to pay a legalization fee of $1,080 \mathrm{XOF}[\sim \$ 2.00]$ per square meter, which is about four times more than the price we were quoted earlier this year. He said that this fee could be reduced by $20 \%$ or more if we were willing to enter in to a partnership with Camara that would provide free or discounted classes to Camara staff and their children.

These shifting "rules of the game" make it difficult for tertiary educational initiatives to operate in this unstable political terrain. Furthermore, costs associated with these political transitions, in terms of money and time, potentially lead to donor-collaborator fatigue and withdrawal (Lundy, Patterson, and O'Neill 2017).

The WAVS respondent also expressed similar difficulties over getting their degree programs accredited/recognized by the national government: "The school attempted on several occasions to get certification with INAFOR (Instituto Nacional de Formação Técnica e Profissiona) but the process was never completed due to excessive fees or stipulations." These barriers to tertiary education are exacerbated by structural violence.

\section{Structural Violence}

Structural violence, in which inadequate social institutions are considered harmful because they prevent people from meeting their basic needs and fulfilling their potential, is a real barrier to achieving individual and national growth and development in tertiary education (Galtung 1969; Rodney 1982). One respondent lamented, "Some of the challenges that must be addressed are quality programming (including quality teachers), affordability, and creating/providing/ensuring job opportunities for graduates." Another opined, "the major constraints of the institution ... are (i) lack of commitment to quality education, (ii) lack of horizontal relationships between students and professors, (iii) sexual harassment and misogyny, (iv) professors not questioning their teaching and evaluation methods, and (v) a lack of access to literature (e.g., books, papers) or an adequate internet signal." While Amartya Sen referred to these barriers as "unfreedoms", Paul Farmer (2005) summarized structural violence as, "offensives against human dignity: extreme 
and relative poverty, social inequalities ranging from racism to gender inequality, and the more spectacular forms of violence that are uncontestedly human rights abuses" (8).

A third illustration of this theme pulled from the data that expressed these manifestations of structural violence in Guinea-Bissau was described thusly:

Rural and informal knowledge is seen as backward and unimportant when judged against university knowledge. A critical analysis of knowledge transmitted at the university is lacking and sometimes it is through the university that stereotypes are reproduced and legitimized. Interdisciplinarity and critical thinking should help deconstruct hierarchies of knowledge and challenge oversimplified generalizations and stereotypes. It would be desirable that the university would work as place to re-think society; exchanges with other Lusophone countries and subregional countries could be an interesting starting point.

In this response, the respondent both describes the problem and offers up a possible solution: interdisciplinarity leading to critical thinking and the critical analysis of knowledge transmitted at the university. However, for this solution to become effective, not only would there need to be a rethinking of educational priorities in Guinea-Bissau, but also those benefiting from these enlightened perspectives would need to stay and transmit this knowledge to others, which for the most part, is not happening. Therefore, I next turn to the idea of "Brain Drain".

\section{Brain Drain}

Rodney (1982) describes the absurdity of the "brain drain" in Africa as follows,

This is to say, professionals, technicians, high-level administrators, and skilled workers emigrate from their homes, and the small number of skilled people available to the underdeveloped world is further depleted by the lure of better pay and opportunities in the developed world. This lopsided nature of the present international economy is strikingly brought home by the fact that the underdeveloped countries must in turn recruit foreign experts at fantastic costs. (18)

In describing this situation, one respondent explained,

Not only is this the case in all of Guinea-Bissau, but I also see brain drain happening in [the rural areas]. Often times, once students receive training from the [rural] school ..., they move to Bissau where there are more opportunities to use their skills. This brain drain makes it difficult to find qualified teachers to fill the positions at the school. In talking to our students ..., most of them dream of going to school outside the country but this is not always financially possible.

Another said, "Several researchers and professors left the academy to work in nongovernmental organizations or international institutions. Recently some technicians received training outside [of Guinea-Bissau], in Europe (e.g., Portugal) or Africa (e.g., Senegal), and returned to the country to work in private companies and private universities." While a third respondent acknowledged, "In Bissau, it is clear that there is a brain drain to the international and non-governmental organizations absorbing many of the people holding degrees. Since international organizations pay above average 
salaries, it is unlikely that experienced professionals will be interested in teaching at a university where they would be paid lower salaries/amounts per hour."

Here we see the complex nature of this phenomenon: educated elites migrating to other countries and staying; highly-skilled youth fleeing the countryside for the cities; professionals leaving public service and entering private business and international organizations. Therefore, this phenomenon is not always about the loss of human resources, but it is also about reshuffling highly-skilled and educated workers toward foreign and private initiatives and away from civil society and public service. This then likely intensifies inequality and underdevelopment and perpetuates structural violence. So, based on the potential correctives to problems associated with tertiary education throughout Africa highlighted above, what can be done for the case of Guinea-Bissau? Some of the possible solutions are presented next.

\section{Strategic Integration}

Consistency, transparency, and fairness were all highlighted in regard to policy development and implementation for effective tertiary education initiatives (Finnegan, Atim, and Westerhaus 2013; Paracka 2013). One success story in this arena emphasized by a respondent was, "Due to changes in the process and INAFOR policy, this year, 2017, the school finally got certification in auto-mechanics, welding, and computer with INAFOR. All diplomas in these three areas will now have an INAFOR stamp of approval. The school is currently working to get the English program certified through another entity." A second responded was now certain that the Ministry of Education was tracking the quality of tertiary education: "The University is under the Ministry of Education. This Ministry has an Office oriented to higher education which the main goal is the quality control of education service." Therefore, as the structures and institutions solidify around the implementation and management of tertiary education, it becomes essential to put measures in place that will prevent any future derailment even in the face of political uncertainty at the highest levels such as meaningful partnerships, sometimes referenced as Memoranda of Understanding (MOUs).

\section{Collaboration}

One way to promote the continued success of tertiary education in Guinea-Bissau even in the face of political and economic uncertainty is to establish balanced, reciprocal, and collaborative partnerships that can offer a safe harbor (Ellison 2013; Finnegan, Atim, and Westerhaus 2013; Negash and Bass 2013; Paracka 2013). Some of these collaborative projects emphasized by the respondents in relation to their work and the work of their tertiary institutions follow. One respondent suggested,

The school has partnered with WellFound, a UK based NGO, the last four years to offer a three-week intensive training course in water pump repair and building latrines. In 2016, WAVS launched the New Entrepreneurs Program (NEP), which provides tools and materials at an affordable cost to our graduates. WAVS is currently [since 2015] working with Jean Piaget University and the Guinea-Bissau government to acquire land in the country's capital to expand and build a second campus that will eventually serve 1,000 students per year.

Another conveyed,

I have worked as an assistant professor in private universities (e.g., Lusophone University, University Colinas de Boé) teaching research methodology in the Social Sciences. I have collaborated (2015-16) as an 
assistant professor at [a U.S.-based university]. I'm also a senior researcher at the National Institution for Social Research (INEP).

A third respondent explained, "The University has support from the sub-regional organization UEMOA and UNESCO for equipment and training in ICT. This support allowed the establishment of a new course." A fourth sentiment expressed, "During this last year there was an informal collaboration with the Faculty of Sciences of the University of Lisbon for the identification of a few biological samples. I have participated in a few activities at the Escola Normal Superior Tchico Té."

Just considering the few responses above, there are clear collaborative initiatives, partnerships, joint-research and programming, and more with local, regional, national and international bodies including other universities, NGOs, regional bodies, governments, and international organizations. The hope is that these enterprises lead to increased capacity and quality for Guinea-Bissau's tertiary education.

\section{Building Capacity}

Next, there were several mentions of capacity building in the data. In citing an important resource, one respondent stated that they had "quality, well-trained teachers both in their field of expertise and in teaching pedagogy." In reference to their institutional history, another responded recounted,

West African Vocational Schools (WAVS) has been operating in GuineaBissau since 2000. The first WAVS school opened in 2006 with a small auto mechanics program. The following year, the school added a sewing program and computer basics program. Additional courses followed: English in 2011, welding in 2012, and French in 2014. To date, the school has provided life-changing job skills to more than 800 women and men. The school now reaches 200 students each year. ... This [new] campus will allow WAVS to expand its training programs to other in-demand areas such as construction, agriculture, and solar power.

Similarly, another reported,

It's a public university. It needs financial support from the state. Recently it has had enough support. ... The university was create by the governmental resolution, Decreto-Lei n'6/99 December 6th. It established an agreement with Lusophone University from Portugal between 2004 and 2007. ... In 2013, the University began new reforms with the nomination of a Rector and a new staff. The new courses only start this year [2017]. ... Our institution recently began new academic programs. It offers courses in two main degree programs: Information Technology and Communication (TIC); Agriculture and Environment.

This same respondent continued, "The University begins its new program this year [2017]. We already have 300 students. The University plans to double the number each year, gradually. The level for admission is the High School diploma." While a third responded related, "I know that Nursing admits 300 students a year and Environmental Management and Oceanography admits around 60-70."

Each of the three institutions surveyed expressed clear plans for expansion, while they were already responsible for educating approximately 900 students per year. According to the Government of Guinea-Bissau's (2010) "Three-year Plan for the Development of Education: 2011-2013", by 2020, they want to realize 1,800 public and 
private students being trained in technical and vocational courses as well as 6,285 students enrolled in public, private, and distance learning higher education programs (Table 1). Given the current plans for expansion by the three tertiary education institutions under consideration, this goal seems achievable.

Table 1

Enrollment Goals in Tertiary Education for Guinea-Bissau, 2006, 2020

\begin{tabular}{|c|c|c|}
\hline Technical and Vocational Training & $\underline{\text { Year } 2006}$ & Year 2020 \\
\hline $\begin{array}{l}\text { Number of students on short-term vocational training } \\
\text { courses (graduating from PE or SE) in the public system }\end{array}$ & 423 & 6,849 \\
\hline$\%$ graduating from 6 th year and 9 th year & $5 \%$ & $15 \%$ \\
\hline $\begin{array}{l}\text { Number of students on technical and vocational courses in } \\
\text { the public system }\end{array}$ & 251 & 800 \\
\hline $\begin{array}{l}\text { Number of students on technical and vocational courses in } \\
\text { the private system }\end{array}$ & $\mathrm{O}$ & 1,000 \\
\hline \multicolumn{3}{|l|}{ Higher Education } \\
\hline Students/ 100000 inhabitants & 224 & 250 \\
\hline Numbers enrolled in public system & 3,000 & 1,500 \\
\hline Numbers enrolled in private system & 689 & 3,785 \\
\hline Numbers on distant learning schemes & 0 & 1,000 \\
\hline $\begin{array}{l}\text { Expenditure per student in GDP unit/inhabitant (both } \\
\text { public and private funding), other than social expenditure }\end{array}$ & 1,6 & 3 \\
\hline $\begin{array}{l}\text { Expenditure on study abroad, as \% of total local } \\
\text { expenditure }\end{array}$ & $237.50 \%$ & $20.00 \%$ \\
\hline \multicolumn{3}{|l|}{ Scientific Research } \\
\hline er education expenditure (public + private) & $16 \%$ & $20 \%$ \\
\hline Share of public funding & $41 \%$ & $40 \%$ \\
\hline
\end{tabular}

Source. Government of Guinea-Bissau $(2010,16)$.

\section{Localized Realities}

However, many impediments to achieving these national level tertiary educational goals remain. Some of those expressed by respondents include: "Unfortunately, right now, many students are leaving the country to pursue higher education because of the lack of quality programs in Guinea-Bissau. However, with an investment in quality higher education, there is a whole generation ready to enroll." Another respondent believed, "The most important available resources at the institution where I am based at the moment are the variety of degrees available and the enthusiasm of students to learn and improve (if they are given an opportunity to work on the individual and specific challenges posed by the previous education settings)." Similarly, another respondent articulated, "Students are eager to know more and several invest considerable time and funds on trying to improve their skills." Finally, in considering the on-the-ground reality facing students enrolled in tertiary education in Guinea-Bissau, another lamented,

There are several constraints to the development of higher education in Guinea-Bissau; it is difficult to be optimistic in the short term since there is no commitment to education quality and the state is not able to ensure either adequate and effective legislation or a budget supporting education. Moreover, students completing the secondary education would require at least a year of preparation to the university in accordance with what is 
demanded at the university level, otherwise teaching demands at the university level tend to decrease.

Therefore, what is the potential of tertiary education in Guinea-Bissau?

\section{Future Potential of Tertiary Education in Guinea-Bissau}

One optimistic respondent reasoned, "In any context, the key to knowledge creation, preservation, and intervention is passionate individuals who are interested in a topic and given the freedom and capabilities to pursue and share that knowledge with others." They felt that Guinea-Bissau could offer students this chance to passionately and freely pursue knowledge creation. Another voiced, "The future of higher education in Guinea-Bissau is bright but there is a lot of work ahead. More and more students are interested in pursuing a degree from a higher education institution." A third respondent saw tertiary education as the key to future economic success for Guinea-Bissau: " $\sqsubset$ Higher Education] will be an important tool for the development of the country. It can help to improve the educational level of youth and help them to organize new initiatives for employment and social services." Taking a more practical and needs' based approach, a last respondent specified,

Given the lower quality of the current primary and secondary education, it is crucial to offer facilities that prepare students for university and support them throughout their courses of study. Language courses, writing courses, fundaments of different disciplines, would all be important for students. If given individual and adequate attention, some students improve very fast and are able to overcome the deficiencies of a low quality elementary and secondary education.

In sum, these findings showcase both the challenges and opportunities in relation to Guinea-Bissau's tertiary education system and for institutions within it. Considering these findings, this article concludes with a brief presentation of a proposed educational program and explains why this program seems appropriate for the Guinea-Bissau.

\section{Project Proposal}

The proposal titled Understanding Human Ecology in Guinea-Bissau was submitted to the Fulbright Specialist Host Institution Project through the Program Specialist at the Public Affairs Section of the U.S. Embassy, Dakar on August 10, 2017. This proposal was submitted based on the objectives of the interim "Three-year Plan for the Development of Education 2011-2013", implemented by the government of GuineaBissau in partnership with and funded through the United Nations Children's Fund (UNICEF), the International Bank for Reconstruction and Development (IBRD), and others under the "Education for All" policy.

The Three-year Plan outlined a number of significant objectives for education policy to pursue including: "Improve higher education and promote scientific research in order to ensure that the needs of society and demands of the economy are met" (2010, 13). Furthermore, this plan outlines a need for private sector's role in both vocational training and higher education. As an underfunded sector of the economy, there are less than 5,000 Bissau-Guinean students in higher education, which is much lower than the proportion of the population when compared with both francophone and anglophone Africa. The Three-year Report identified and proposed the role of the state in higher education to include "the creation of a framework for scientific development" such as the "endorsement of training models" and "the organization of teachers' ongoing training (including research, in partnership with centers abroad)" (2010,30). 
According to those already involved in higher education instruction in GuineaBissau: "many students lack experience in research and need to find creative solutions to improve overall student writing. Reading, researching, and writing about something tangible that integrates their environments, geographies, social memories, and expectations should be a good approach to training students in higher education" (personal communication, July 5, 2017).

Therefore, the issue or challenge that is proposed to be addressed is improving higher education and promoting scientific research to meet the demands of society and the economy. Guinea-Bissau's economy is based primarily on agriculture (i.e., cashews and rice), fishing, and resource extraction (i.e., timber and bauxite), all of which have dramatic effects on the populations' livelihoods and environments (Lundy 2012, 2014). This in turn impacts the country's overall wellbeing. The proposed project partners with administrators, faculty, and students to help find evidence-based solutions to some of Guinea-Bissau's most pressing concerns in line with the United Nations set of goals to end poverty, protect the planet, and ensure prosperity for all as part of a new sustainable development agenda. The proposal's goals are to develop an academic toolkit including curriculum development (e.g., Environmental Studies degree program), course preps (e.g., Research Methods in Anthropology, Environmental Anthropology Field Methods), collaborative research, and shared resources (e.g., joint publications).

The three objectives of the proposal are to: (1) share best practices on teaching and conducting qualitative research methods such as ethnography through a series of seminars and workshops with Universidade Amílcar Cabral and Universidade Lusófona da Guiné administrators, faculty, and students; (2) assist in the development of a human ecology / environmental studies curriculum including a methodology course on Agriculture and Environment; and (3) assist in the development and publication of a human ecology /environmental studies textbook specific to Guinea-Bissau and West African contexts.

The proposal aims to build a research focus and public-private programming in the area of Environmental Studies that benefits all institutional stakeholders. This program of study is designed to give students an overview of the human dimensions of Guinea-Bissau's environmental issues. Students will be introduced to technologies and approaches used by social scientists to study environmental issues. The program participants will examine patterns arising from the ways in which people manage and exploit natural resources and the environment. Furthermore, the program will embrace the concept of sustainability and sustainable development in theory and practice allowing students to analyze ideological arguments, sustainability indicators, and other metrics and tools including case studies to evaluate sustainability projects worldwide. Students will also examine different interpretations of sustainability across the globe with special attention given to how sustainability is viewed and implemented in Guinea-Bissau and the West African region. Ultimately, the goal will be to develop a research focus at these two institutions that would attract world-renowned researchers in the field, creating new opportunities for sustained projects, programming, and collaboration internationally for faculty and their students. The program will include a series of co-taught seminars or workshops provided by the hosts and the Fulbright Specialist using the "teaching of trainers" or "skills transference" model from participants to host country counterparts and vice versa.

Furthermore, the project will help design and pilot a research methods course around the theme "Agriculture and the Environment" for interested students and faculty. The use of high impact practices (HIPs) such as hands-on, practice-centered learning should promote relevant and highly valued scientific investigations in the country while simultaneously training university students and faculty in research and writing best practices (Smith, Lundy, and Dahlmann 2017). In other words, students and faculty will 
be asked to identify, through research, a real-world problem (local to global), develop solutions using evidence (i.e., empirical or evidence-based research), and present the solutions in writing. This approach integrates knowing and doing and rewards intangible assets such as drive, passion, creativity, empathy, and resiliency. Furthermore, it is a powerful tool because it is activated through experience (i.e., learning by doing) using one's surroundings for inspiration. As a follow up to the program design and course implementation, a collaborative textbook will be created from a selection of faculty/student cases and translated papers relevant for students based in Guinea-Bissau. The text will accompany the curriculum in Human Ecology / Environmental Studies that could be co-directed at both Universidade Amilcar Cabral and Universidade Lusófona da Guiné with input and exchange from other regional and international partner institutions.

Our proposal can help continue the momentum toward improving the capacity of tertiary education in Guinea-Bissau as well as help to build on previously attempted public-private partnerships. The Sociology degree (Sociologia) at Universidade Lusófona da Guiné already has courses on the Introduction to Qualitative Analysis, Anthropology, and Ecology and Human Geography. This project builds on these offerings and should elevate the curriculum of both institutions with alternative perspectives, hands-on research, writing-intensive requirements, and deliverables in the form of a published textbook useable in several of the course offerings.

\section{Conclusion}

What this proposal suggests is that we can build collaborative, transparent, and reciprocal programming across institutions and beyond existing barriers to promote and advance tertiary education. Through the examination of best practices and lessons learned being implemented elsewhere on the continent, we have seen successes from peerto-peer and educating-the-educator models. Therefore, the proposal exemplifies these lessons learned and can hopefully use these best practices to help rebuild tertiary education in Guinea-Bissau.

The small number of participants limited this study; yet this limitation was mitigated by surveying experts knowledgeable about tertiary education in Guinea-Bissau as program and university affiliates and administrators. The next step in this research will be to implement the project and systematically evaluate the results to see if it is able to overcome the severe political, developmental, and structural barriers through the utilization of the identified techniques, resources, and approaches to successful implementation found in other contexts around the continent. In answer to the original question posed in the title to this article, "Can it be done?", only time will tell.

As Martin Luther King Jr. once decried, and world-renowned Africanist Toyin Falola seconded, there remains a need for "networks of mutuality", in other words, forged alliances in education, politics, and business between the United States and Africa. Falola (2013) argues, "There are ways to strengthen the connections between Africa and the world, and vice versa, and then use these connections to generate relevance, progress, development, and peace" (253). He continues, "First, we as scholars have to keep extending the frontier of knowledge, use our resources to transform scholarship in and about Africa, and ensure that our studies also inform mainstream scholarship" (Falola 2013, 253). Falola concludes, "We [as university educators] have the special role to link the Americas with Africa, the academy with the public, and knowledge with occupations" $(2013,254)$. One way to achieve this lofty goal is through serious engagement with burgeoning institutions of tertiary education. 


\section{References}

Agence France-Presse (AFP). (2017, July 14). Guinea-Bissau parents coax truant teachers back to school. Daily Mail. Retrieved from http://www.dailymail.co.uk/wires/afp/article-4696898/Guinea-Bissau-parentscoax-truant-teachers-school.html

Boehler, P., \& Ceesay, S. (2013, June 19). West Africa a shortcut for rich mainland Chinese to Hong Kong residency. South China Morning Post. Retrieved from http://www.scmp.com/news/hong-kong/article/1264161/west-africashortcut-rich-mainland-chinese-hong-kong-residency

Boone, P., Fazzio, I., Jandhyala, K., Jayanty, C., Jayanty, G., Johnson, S., Ramachandrin, V., Silva, F., \& Zhan, Z. (2013). The Surprisingly Dire Situation of Children's Education in Rural West Africa: Results from the CREO Study in Guinea-Bissau (Comprehensive Review of Education Outcomes). NBER Working Paper Series, Working Paper 18971. Retrieved from http://www.nber.org/papers/w 18971

Cabral, A. (1969). Revolution in Guinea: Selected Texts by Amilcar Cabral. (R. Handyside, Trans.). New York: Monthly Review Press.

Chabal, P., \& Green, T. (Eds.). (2016). Guinea-Bissau: Micro-State to 'Narco-State'. London: Hurst and Company.

Dhada, M. (1993). Warriors at Work: How Guinea Was Really Set Free. Niwot, CO: University of Colorado Press.

Ellison, J. (2013). Teaching Culture, Health, and Political Economy in the Field: GroundLevel Perspectives on Africa in the $21^{\text {st }}$ Century. In B. D. Lundy \& S. Negash (Eds.), Teaching Africa: A Guide for the 21st-Century Classroom (pp. 211-224). Bloomington: Indiana University Press.

Falola, T. (2013). Conclusion: Knowledge Circulation and Diasporic Interfacing. In B. D. Lundy \& S. Negash (Eds.), Teaching Africa: A Guide for the 21st-Century Classroom (pp. 253-256). Bloomington: Indiana University Press.

Farmer, P. (2005). Pathologies of Power: Health, Human Rights, and the New War on the Poor. Berkeley: University of California Press.

Finnegan, A. C., Atim, J. J., \& Westerhaus, M. J. (2013). Beyond the Biological Basis of Disease: Collaborative Study of the Social and Economic Causation of Disease in Africa. In B. D. Lundy \& S. Negash (Eds.), Teaching Africa: A Guide for the 21stCentury Classroom (pp. 225-239). Bloomington: Indiana University Press.

Freire, P. (1978). Pedagogy in Process: The Letters to Guinea-Bissau. (C. St. John Hunter, Trans.). New York: The Seabury Press.

. (1996). Pedagogy of the Oppressed (Revised Edition). New York: Continuum.

Freire, P., \& Macedo, D. P. (1995). A Dialogue: Culture, Language, and Race. Harvard Educational Review, 65(3), 377-402.

Galtung, J. (1969). Violence, Peace, and Peace Research. Journal of Peace Research, 6(3), 167-191.

Global Partnership for Education. (2017). Guinea-Bissau. Retrieved from http://www.globalpartnership.org/country/guinea-bissau, accessed September 19.

Green, T. (2016). Introduction. In P. Chabal \& T. Green (Eds.), Guinea-Bissau: MicroState to 'Narco-State' (pp. 1-16). London: Hurst and Company.

Harasim, L. M. (1983). Literacy and National Reconstruction in Guinea-Bissau: A Critique of the Freirean Literacy Campaign (Ph.D. dissertation). Department of Educational Theory, University of Toronto, Toronto, Canada.

IRIN. (2003, November 14). Government opens first university. IRINnews.org, Bissau. Retrieved from http://www.irinnews.org/report/47256/guinea-bissaugovernment-opens-first-university 
(2013, May 30). Guinea-Bissau still way behind on education. IRINnews.org, Bissau. Retrieved from http://www.irinnews.org/report/98129/guinea-bissaustill-way-behind-education

Kohl, C. (2016). Ethnicity and the Political System Post-1998. In P. Chabal \& T. Green (Eds.), Guinea-Bissau: Micro-State to 'Narco-State' (pp. 161-184). London: Hurst and Company.

Langa, P. V. (2013). Higher Education in Portuguese Speaking African Countries: A Five Country Baseline Study. South Africa: African Minds.

Lundy, B. D. (2012). Playing the Market: How the cashew 'commodityscape' is redefining Guinea-Bissau's countryside. Culture, Agriculture, Food and Environment (CAFÉ), 34(1), 33-51.

http://onlinelibrary.wiley.com/doi/10.1111/j.2153-9561.2012.01063.x/abstract . (2013). Cabral and Freire: The Importance of Cultural Capital in Rebuilding a Successful Education System in Guinea-Bissau. In F. Manji \& B. Fletcher Jr. (Eds.), Claim No Easy Victories: The Legacy of Amilcar Cabral (pp. 365-378). Dakar, Senegal: CODESRIA.

. (2014). Monitoring Conflicts of Interest: Social Conflict in Guinea-Bissau's Fisheries. In A. G. Adebayo, J. J. Benjamin, \& B. D. Lundy (Eds.), Indigenous Conflict Management Strategies: Global Perspectives (pp. 151-165). Lanham, MD: Lexington Books.

Lundy, B. D., Patterson, M., \& O’Neill, A. (2017). Drivers and Deterrents of Entrepreneurial Enterprise in the Risk Prone Global South. Economic Anthropology, 4(1), 65-81.

Marquardt, G. (2013). Answering the "So What" Question: Making African History Relevant in the Provincial College Classroom. In B. D. Lundy \& S. Negash (Eds.), Teaching Africa: A Guide for the 21 st-Century Classroom (pp. 53-60). Bloomington: Indiana University Press.

Massey S. (2016). Global Geopolitics and the Failure of Securitization in Guinea-Bissau. In P. Chabal \& T. Green (Eds.), Guinea-Bissau: Micro-State to 'Narco-State' (pp. 185-203). London: Hurst and Company.

Negash, S., \& Bass, J. M. (2013). Educating the Educators: Ethiopia's IT Ph.D. Program. In B. D. Lundy \& S. Negash (Eds.), Teaching Africa: A Guide for the 21st-Century Classroom (pp. 240-252). Bloomington: Indiana University Press.

Nkrumah, K. (1965). Neo-colonialism: The Last Stage of Imperialism. New York: International Publishers.

Paracka Jr., D. J. (2013). The Kalamazoo / Fourah Bay College Partnership: A Context for Understanding Study Abroad with Africa. In B. D. Lundy \& S. Negash (Eds.), Teaching Africa: A Guide for the 21st-Century Classroom (pp. 202-2 10). Bloomington: Indiana University Press.

Pityana, N. B. (2013). Cabral, Culture, and Education. In F. Manji \& B. Fletcher Jr. (Eds.), Claim No Easy Victories: The Legacy of Amilcar Cabral (pp. 378-386). Dakar, Senegal: CODESRIA.

Republic of Guinea-Bissau. (2010, March). Three-year Plan for the Development of Education: 2011-2013. Ministry of National Education, Culture, Science, Youth and Sports.

Reuters. (2017, July 19). Guinea Bissau reaches $\$ 47$ million deal on submarine cable. Reuters. Retrieved from https://www.reuters.com/article/us-bissaueconomy/guinea-bissau-reaches-47-million-deal-on-submarine-cableidUSKBN 1A414B

Rodney, W. (1970). A History of the Upper Guinea Coast 1545-1800. New York: Monthly Review Press. 
. (1982). How Europe Underdeveloped Africa (New Edition). Washington, DC: Howard University Press.

Sami, O. (2008, November 3). Extinção da Universidade Amílcar Cabral: Grupo Lusófono cria universidade na Guiné-Bissau. Portuguese News Network.

Santos, J. G. d., \& Silva, R. d. (2017). Theory and praxis: reflections and lessons from a bilateral educational aid programme in Guinea-Bissau. Globalisation, Societies and Education, 15(2), 202-216.

Shipman, E. (2015, March 25). Guinea-Bissau Struggles to Provide Education. Borgen Magazine. Retrieved from http://www.borgenmagazine.com/guinea-bissaustruggles-provide-education/

Silva, R. d., Santos, J. G. d., \& Pacheco, J. A. (2015). Crossed looks: globalisations and curriculum in Guinea-Bissau. Compare: A Journal of Comparative and International Education, 45(6), 978-999.

Silva, R. d., \& Oliveira, J. (2017). 40 years of educational research in Guinea-Bissau: Mapping the terrain. International Journal of Educational Development, 57, 21-29.

Smith, S. K., Lundy, B. D., \& Dahlmann, C. (2017). High-Impact Practices in Anthropology: Creating a Bridge between Liberal Arts and Neoliberal Values. Georgia Journal of Science, 75(2), 1-14.

http://digitalcommons.gaacademy.org/gjs/vol75/iss2/9/

Temudo, M., \& Abrantes, M. (2015). The Pen and the Plough: Balanta Young Men in Guinea-Bissau. Development and Change, 46(3), 464-485.

UNDP. (2016). Guinea-Bissau: Briefing note for countries on the 2016 Human Development Report. Human Development Report 2016. Retrieved from http://hdr.undp.org/sites/all/themes/hdr_theme/country-notes/es/GNB.pdf

UNICEF. (2016, February). Support to Education for All Implementation in GuineaBissau. Progress Report to the Global Partnership for Education (GPE).

Urdang, S. (1979). Fighting Two Colonialisms: Women in Guinea-Bissau. New York: Monthly Review Press.

Vigh, H. (2006). Navigating Terrains of War: Youth and Soldiering in Guinea-Bissau. New York: Berghahn Books.

. (2012). Critical states and cocaine connections. In M. Utas (Ed.), African Conflicts and Informal Power: Big Men and Networks (pp. 137-157). New York: Zed Books.

The World Bank Group. (2016). Government expenditure on education as a \% of GDP (\%). The World Bank. Retrieved from https://data.worldbank.org/indicator/SE.XPD.TOTL.GD.ZS?locations=GW, accessed September 19.

Yaoti, R. (2016, October 24). As China enrolls more overseas students to build soft power, locals find the process unfair. Global Times. Retrieved from http://www.globaltimes.cn/content/1013390.shtml

\section{About the Author}

Brandon D. Lundy is an Associate Professor of Anthropology and an Associate Director in the School of Conflict Management, Peacebuilding and Development at Kennesaw State University. He serves as the Editor of the journal Economic Anthropology and as an Associate Editor for the Journal of Peacebuilding and Development. Receiving his PhDs from SUNY at Buffalo and the University of Science and Technology of Lille, France, Dr. Lundy's work focuses on sustainable livelihoods including food security, ethnoeconomics, transnational labour migration, and entrepreneurship. He is the editor or co-editor of five books including two on Indigenous Conflict Management Strategies (Lexington Books, 2014, 2015) and one on Teaching Africa (Indiana University Press, 2013). He has published in many edited books and 
journals including Development in Practice (2018), the Journal of International Migration and Integration (2018), Border Crossing (2017), Economic Anthropology (2017), African Arts (2016), and African Identities (2015). Dr. Lundy has served as a country specialist (Guinea-Bissau) for the State Department and regularly presents nationally and internationally. After participating in a Fulbright-Hays in the summer of 2016 in Senegal on "Religion and Diversity in West Africa", he became a Fulbright Specialist. His first project as a Fulbright Specialist is on environmental studies in Guinea-Bissau (2018). 